\title{
The sequencing of stock market liberalization events and corporate financing decisions
}

\author{
Thomas O'Connor* \\ Department of Economics, Finance and \\ Accounting \\ National University of Ireland Maynooth, \\ Maynooth, \\ Co. Kildare, \\ Ireland.
}

\author{
Thomas Flavin \\ Department of Economics, Finance and \\ Accounting \\ National University of Ireland Maynooth, \\ Maynooth, \\ Co. Kildare, \\ Ireland.
}

\begin{abstract}
We examine if the sequence of stock market liberalization events matters for corporate financing choices. We contrast firms who attain 'investable' status through domestic reforms with those who do so by issuing American Depository Receipt programs. We find that the first liberalization event prompts similar corporate responses regardless of the path followed. However, we find differential effects between firms who issue ADRs after realizing financial liberalization and those who use ADR initiations to achieve this status. Here, the sequence matters and the capital structure choices of the two groups are very different.
\end{abstract}

JEL Classification: F30; G15; G32.

Key Words: Financing choices; Debt structure; Investability; Cross listing.

\footnotetext{
* Contact author.

E-mail: Thomas.g.oconnor@nuim.ie

Telephone: +0035317086667.
} 


\section{Introduction}

Financial liberalization programs became popular across many emerging markets over the past three decades. The promise of increased liquidity, deeper financial markets, enhanced efficiency of trading systems, together with greater transparency and legal enforcement of financial contracts made these programs attractive to financial market participants. Many countries and their indigenous firms have made great strides to eliminate both country-level and firm-level restrictions on the ability of foreign investors to become stakeholders in their corporations, with large global institutions encouraging these initiatives and providing the expertise for their implementation. Such programs were designed to reduce the financial constraints that may have limited the growth and expansion of emerging market firms due to an inability to raise capital domestically at internationally competitive prices. Empirical studies find that stock market liberalizations and international cross listings relax financing constraints, improve operating performance, and promote growth for these firms (see Henry, 2000; Chari and Henry, 2004; Gupta and Yuan, 2004; Li, 2003; and Mitton, 2006 for the stock market liberalization view, and Lins et al., 2005; Khurana et al., 2008; and Charitou and Louca, 2009 for the cross listing view). For previously constrained firms, financial market liberalization allows them to move to their optimal capital structure and following the implementation of such programs, we often observe changes to corporate financing decisions. For example, corporations often re-adjust their leverage ratios due to greater access to capital markets and potentially due to a change in the relative price of debt and equity. Furthermore, the maturity structure of the debt portfolio may change as firms seek to increase the long-term debt component and hence reduce their reliance on short-term debt and their exposure to rollover risk. We seek to shed further light on these issues by explicitly taking account of the sequence of events that leads to the financial liberalization of the firm.

A popular and direct avenue of entry to international capital markets for many firms is to 'crosslist' their stock on US equity markets via an American Depository Receipt (ADR) program. The growth of this investment vehicle over the 1980s and 1990s testifies to the fact that many firms availed of this path to liberalization. For example, at its height in 2000, the number of exchange-traded Level $2 / 3$ issues numbered 608, compared to just 176 in 1990. Non-exchange programs (i.e., Level 1 and Rule 144a issues) were even more popular. In 2000, the number of Level 1 programs stood at 717, and unlike Level 2/3 
issues, maintained this level in subsequent years (see Bank of New York, 2005). ${ }^{1}$ Other firms preferred not to initiate an ADR program but in conjunction with improved country-level investor protection sought to eliminate barriers to inward investment. These firms were deemed to be 'investable', provided firm- and country-level restrictions on foreign ownership were eliminated. ${ }^{2}$ Interestingly, these liberalization programs are not mutually exclusive and many firms have 'cross-listed' their stock via an ADR program subsequent to being deemed investable. The sequence of events chosen by firms may result in different corporate decisions but this has received little attention in the extant literature.

The impact of 'cross listing' via an ADR program on corporate capital structure has received some attention in recent years. Reese and Weisbach (2002) predict that all 'cross listing' firms will issue more equity capital post-listing, regardless of the type of ADR. Furthermore, firms from countries with relatively weak investor protection should increase their equity financing more than those domiciled in countries with strong investor protection. Lins et al. (2005) provide empirical evidence that is consistent with this hypothesis. All firm classifications in their sample issue more equity post-listing with a larger effect found for emerging market firms relative to those from developed markets. More recently, Fan et al. (2009) and Wu (2009) find evidence that firms employ more equity post-listing but the former find no statistical evidence that firm behavior differs by level of corruption in the domestic country. Less attention has been reported to the debt maturity issue. However, Fan et al. (2009) report that firms increase the maturity structure of their debt post-listing in the US and the greater proportion of long-term debt employed is more evident in countries with high corruption.

We address two important issues regarding the impact of financial liberalization on corporate decision-making, both in relation to the capital structure and the maturity of debt employed in financing the operations of the firm. Firstly, we ask if the path to liberalization is important in the determination of these corporate decisions, i.e. do firms that are deemed investable but never cross-list in the US behave

\footnotetext{
${ }^{1}$ Others sought a strategic alliance in preference to an international cross listing. Siegel (2008) shows that under certain conditions, a strategic alliance with a foreign multinational can be a superior mechanism for improving corporate governance.

2 In addition to being free from firm- and country-level foreign ownership restrictions, stocks must also have sufficient size and liquidity to be realistically available to foreign investors to be fully deemed investable.
} 
differently to those firms who become liberalized through the issuance of an ADR. Secondly, we analyze the response of firms who issue ADRs. We continue to distinguish ADR issues by type, but our main innovation is to further distinguish them by their place in the sequence of 'liberalization acts'. ${ }^{3}$ We contrast the choices of two types of cross-listed firm; those who become liberalized because they issue an ADR versus those who were previously deemed investable and subsequently issue an ADR. Our hypothesis is that the financing decisions of these two groups may differ due to the 'timing' of the ADR listing and that results of previous studies that ignore the sequence of liberalization events may mask important differences across firms. Our results reveal a number of interesting insights to corporate decision-making. Firstly, there is little difference between firms who pursue different liberalization paths. Both types of firm reduce debt and increase equity, while the maturity structure of debt is largely unaffected. Secondly, the sequence of liberalizations events is important in determining how the issuance of an ADR affects the capital structure. When the ADR represents the first act of liberalization, the firm typically takes on more equity and reduces debt. However, for firms who have previously been deemed 'investable', the ADR listing is associated with a greater proportion of debt financing. Thirdly, classifying listings by type is crucial as the behavior of firms who bond to US governance differs from those who do not and we also see differences between firms who acquire the ability to raise capital in the US and those who return to their domestic capital markets to finance corporate expansion. Finally, the maturity structure of corporate debt is largely unaffected by the sequence of liberalization events, except for Level 2 ADRs who appear to increase their proportion of long-term debt, when the issue is subsequent to being deemed investable.

The paper is structured as follows; section 2 describes the data and presents summary statistics. Section 3 introduces our econometric methodology, while section 4 presents and discusses our results. Section 5 contains our concluding remarks.

\footnotetext{
${ }^{3}$ Sarkissian and Schill (2009) find that the sequencing of multiple international cross listings matters in determining their impact on firm value.
} 


\section{Data Description}

To analyze the impact of financial liberalization on firms who were previously constrained in their financing decisions, we choose to work with firms from emerging markets where this constraint is likely to be most binding. Consequently, we begin our data collection at the Emerging Markets Database (EMDB). From this database, we identify all emerging market countries from which firms were deemed investable over our sample period. These countries are: Argentina, Brazil, Chile, China, Colombia, Czech Republic, Egypt, Greece, Hungary, India, Indonesia, Israel, Jordan, Korea, Malaysia, Mexico, Morocco, Pakistan, Peru, Philippines, Poland, Portugal, Russia, South Africa, Sri Lanka, Slovakia, Taiwan, Thailand, Turkey, Venezuela, and Zimbabwe. For each of these countries, we source a full list of firms who have cross-listed in the United States over the period from 1980 to 2007. All information on cross-listed firms is sourced from the Bank of New York, and cross-referenced with information from Deutsche Bank, JP Morgan, the New York Stock Exchange, and Nasdaq. From our cross-listed sample of firms, we classify firms according to their initial cross listing in the U.S. and ignore all subsequent listings changes e.g., upgrades from Level 1 over-the-counter to Level 2/3 exchange traded depositary receipts. To ensure that we correctly identify a firm's initial listing, we consult the historical records from the Bank of New York (since the currently available on-line records only refer to a firm's current - and not the initial - cross listing). Furthermore, this is cross-referenced with a Citibank database in which they flag firms that have changed their cross listing status by including a "successor depositary receipt" data type for all firms. Using both databases, firms are classified as either, a Level 1 over-the-counter; Level 2 and 3 exchangetraded; or a Rule 144a listings that trades on PORTAL to Qualified Institutional Buyers. Unlike Level 1 and Level 2 lists, Level 3 and Rule 144a firms are entitled to raise capital in the U.S. For inclusion in our sample, we require that firms have (financial) data available in both the pre- and post-listing periods. Finally, all countries with no depositary receipts are eliminated from our final sample.

From this sample, we identify all firms that were deemed investable over our sample period using the "investable" measure from the IFC Emerging Market Database (EMDB). The IFC designates a firm as investable if its stock is free from country-level and firm-level restrictions on foreign investment. The IFC also requires that the stocks have sufficient size and liquidity to be realistically available to foreign investors. We define a firm as investable in a given year if its stock appears in the IFC investable index by 
December of that year. From this sample of investable firms, we identify all cross-listed firms that were also previously deemed investable and discard those that were deemed investable as a direct result of cross listing in the U.S. Thus, in our final sample, all joint investable/cross listing firms become investable prior to listing in the U.S. Finally, we also require that all non-investable/non-cross-listed firms have at least 3 years of data.

Our sample is outlined in Table 1. After imposing the data requirements, it comprises of 6,797 firms from 22 countries, corresponding to 49,945 firm-year observations (\#Obs). China provides the largest number of firms (1,395 firms and 8,124 firm-year observations), while Venezuela has the least (9 firms and 80 firm-year observations). We then present the number of investable (Invest) and cross-listed firms (ADR), the number of joint investable/cross-listed firms (ADR \& I), and the median and standard deviation of the difference (in years) between the time in which firms become investable and subsequently cross-list (i.e. Median Diff and Std Dev Diff) by country. In the final columns, we disaggregate our depositary receipt sample into their respective listing types and report the number of Level 1, Level 2, Level 3, and Rule 144a lists, together with the number of joint ADR/Invest firms.

\section{[INSERT TABLE 1 ABOUT HERE]}

Our final sample consists of 731 investable and 189 cross-listed firms. Of these 189 firms, 119 were also deemed investable prior to cross listing in the U.S. The median time between their investable and cross listing years is 3 (with a standard deviation of 3.12 years). Taiwan has the greatest number of depositary receipts with 40, while Argentina, Egypt, Israel, and Turkey provide just 1 each. Similarly, Taiwan also has the greatest number of joint Invest/ADR lists with 17. Argentina, Egypt, and Turkey provide just 1 each. Column 7 shows that the median time between becoming investable and a subsequent cross listing differs greatly across countries. For example, the median cross listing Greek and Malaysian firm, do so, 8 and 11 years respectively after becoming investable. In contrast, firms from Hungary, Russia, Poland, and Venezuela wait just one year. In part, this may be explained by the fact that Greece and Malaysia were liberalized earlier than the second group of countries. ${ }^{4}$ Of the 189 cross-listed firms, 63 are Level 1, 30 are Level 2, 13 are Level 3, and finally 83 are Rule 144a lists. Of these, 41 are joint Level

\footnotetext{
${ }^{4}$ Using the official liberalization dates from Bekaert et al. (2005), Greece and Malaysia officially liberalized their equity markets in 1987 and 1988, respectively. They do not report any dates for Hungary, Russia or Poland.
} 
1/Investable firms, 27 and 6 are joint Level 2/Investable and Level 3/Investable firms, respectively, and 42 are joint Rule 144a/Investable firms.

We examine the joint effects of investability and cross listing on the capital structure and the debt maturity structure of firms. We employ two measures of corporate debt, namely 'Book Debt', defined as the ratio of total debt to total book assets, and 'Net Debt', defined as net debt (total debt less cash) to total assets. We measure equity as either the log of common equity - Log (Equity) - (in US\$), or the ratio of common equity to assets (Equity/Assets). We characterize the debt structure of firms using long and short-term debt to assets (LTD Assets/STD Assets), and long and short-term debt to equity (LTD Equity/STD Equity), and the debt maturity structure of firms using long-term debt to total debt (LTD Total). In addition, we also analyse the joint effects of investability and cross listing on the (total) debtequity ratio of firms (Debt-Equity). Following convention, we exclude financial firms from our final sample ${ }^{5}$ and control for firm-specific factors commonly employed in other related studies (see Agca et al., 2007; Mitton, 2007; and Schmukler and Vesperoni, 2006). Profitability is calculated as the ratio of earnings before interest, taxation, depreciation and amortization (EBITDA) to total assets; growth opportunities as the ratio of market-to-book value of assets; tangibility as the ratio of fixed to total assets; and firm size as the $\log$ of sales (inflation-adjusted and in \$U.S.). ${ }^{6}$ All variables are sourced from Worldscope and are winsorized at the $1^{\text {st }}$ and $99^{\text {th }}$ percentiles.

\section{[INSERT FIGURES 1 - 3 ABOUT HERE]}

For all ADR issuing firms, Figures 1-2 display our capital structure measures and debt maturity ratios respectively, while the corresponding information for the log of common equity (in US\$) is shown in Figure 3. Figure 1 displays the ratios for Level 1 and Rule 144a lists, while Figure 2 presents ratios for

\footnotetext{
${ }^{5}$ Barclay and Smith (1995) and Datta et al. (2005) restrict their sample to firms with SIC codes between 2000 and 5999. As we don't have access to these codes, we use the General Industry Classification data item provided by Worldscope. Based on this classification, firms are assigned to one of six industrial groups: Industrial, utility, transportation, bank/savings \& loan, insurance and other financial. To be consistent with others, we only use the industrial, transportation and utility classifications.

${ }^{6}$ We prefer to use sales, rather than total assets to proxy for firm size, since the latter is used to construct all of the firm-level variables employed in the analysis. The results are similar when we use total assets to proxy for firm size.
} 
Level 2 and 3 exchange-traded firms. The top panels of Figures 1 and 2 presents the median value of the variables in both the pre and post-listing periods for each set of cross listing firms. In general, Level 1 and Level 2 firms tend to issue more debt once they cross-list. In contrast, depositary receipt programs with capital raising facilities in the US (Level 3 and Rule 144a) employ less debt, and more equity, especially in the case of Level 3 firms. Increased equity financing post-listing is also a feature of Level 1 and Level 2 firms (see Figure 3), but unlike Level 3 lists, the increased use of equity financing does not outpace the growth in firm size (assets). Both Level 1 and Level 2 firms employ more long-and short-term debt (relative to equity), but for both, these firms use marginally more short-term debt. Therefore, it is perhaps not surprising that both sets of firms experience an increased debt-equity ratio following a listing. In contrast, debt reliance falls for Level 3 firms (long and short-term), and their increased use of equity leads to reduced debt-equity ratio once they cross-list. Finally post-listing, Rule 144a firms employ more long and short-term debt, and overall use more debt than equity.

We replicate this analysis for cross listing firms depending on whether they were previously deemed investable or not (see middle and bottom panels of Figures $1 \& 2$ and Figure 3). In general, the figures suggest that investability has significant effects on the capital issuance and debt maturity structure of cross listing firms. The pre-listing levels of our variables clearly show that previously non-investable firms are more reliant on debt financing than their investable counterparts. This manifests itself in higher debt to assets and debt to equity ratios for the former group. Arguably this is due to the relatively poor access to equity markets for this group, whereas this restriction has been relaxed for the latter group due to their 'investable' status. This effect is evident from Figure 3. We would expect these pre-listing differences to influence the post-listing financing choices. The observed behavior post-listing confirms our expectations. With the exception of Level 3 lists, all firms employ more debt and more equity in funding the expansion of their balance sheets. However, joint investable/cross listing firms tend to increase the proportion of debt, while their previously non-investable counterparts exhibit a preference for equity capital. For example, Figures 1 and 3 clearly show this for Level 1 listing firms. Furthermore, these investable firms tend to issue more long- and short-term debt, although they use disproportionately more short-term debt. For these firms, and in contrast to non-investables, there is an identifiable increase in their debt-equity ratio. Both sets of Rule 144a firms behave similarly. Non-investable firms use less 
debt, both on an absolute basis and relative to common equity, resulting in a reduced debt-equity ratio. In contrast, investable firms employ more long-term debt, which results in an increased debt-equity ratio. Finally, Figure 3 shows that while all firms issue more equity, the non-investable group exhibits a greater increase in their use of such funding.

Figure 2 contains the summary measures for Level 2 and 3 firms. Level 2 firms behave similarly to Level 1 and Rule 144a issues. Investable firms issue more debt (on an absolute basis and relative to equity), use both short- and long-term, but display a slight preference for short-term debt once they crosslist. The non-investable firms employ less total debt but show a preference for long-term debt and common equity once they cross-list. However, the debt-equity and long-term debt to equity ratios suggest that the preference for long-term debt is stronger. For both sets of Level 3 firms, cross listing is associated with a reduced debt-equity ratio, although the manner in which this is attained differs. Both issue more equity (see Figure 3), but in contrast to other investable firms, Level 3 firms use less debt (both short- and long-term), both absolutely and relative to common equity. In contrast, non-investable Level 3 firms employ more debt and equity, but use proportionately more equity.

\section{Methodology}

Our unconditional summary statistics suggest that joint investable/cross listing firms exhibit very different post-listing capital issuance preferences relative to cross listing firms that were previously not investable. We now examine if these differences remain, once we control for observable and unobservable firm-level characteristics. Specifically, we estimate two-way firm-fixed effects regressions for every dependent variable, using all twenty-two countries in our final sample, with standard errors corrected for heteroscedasticity a la White (1980). We begin by estimating regressions for each of our dependent variables for our entire sample of cross-listed firms. Then, we examine how the post-listing capital issuance choice depends on whether or not the firm was previously deemed investable. Treating all crosslisted firms alike, we estimate the following equation:

$\mathrm{Y}_{\mathrm{i}, \mathrm{t}}=\alpha+\beta \mathrm{X}_{\mathrm{i}, \mathrm{t}}+\gamma_{1} \mathrm{~L}_{\mathrm{i}, \mathrm{t}}+\gamma_{2} \mathrm{~L} 2_{\mathrm{i}, \mathrm{t}}+\gamma_{3} \mathrm{~L} 3_{\mathrm{i}, \mathrm{t}}+\gamma_{4}$ Rule144a $_{\mathrm{i}, \mathrm{t}}+$ Year $_{\mathrm{t}}+$ Firm $_{\mathrm{i}}+\mathrm{e}_{\mathrm{i}, \mathrm{t}}$

where the dependent variable is one of the debt/equity ratios outlined earlier for firm $i$ in year $t$, or one of the maturity ratios. $\mathrm{X}_{\mathrm{it}}$ is a set of firm-level controls (size, profitability, growth opportunities, and 
tangibility), and L1, L2, L3, and Rule 144a are dummy variables that equal one if firm $i$ cross-lists in the U.S. of the indicated type in year $t$ and zero otherwise. Year $_{\mathrm{t}}$ represents a full set of year dummy variables and Firm $_{i}$ are firm-fixed-effects. In all specifications, the dependent variable is regressed on contemporaneous values of the independent variables. ${ }^{7}$ In order to examine how previously being deemed investable matters for post-listing capital issuance choice, we augment equation 1 with interaction dummy variables, whereby we interact each cross listing dummy variable with an investable dummy, which is one if the firm was deemed investable, prior to cross listing in the U.S. Controlling for investability, we estimate the following:

$\mathrm{Y}_{\mathrm{i}, \mathrm{t}}=\alpha+\beta \mathrm{X}_{\mathrm{i}, \mathrm{t}}+\gamma_{1} \mathrm{~L} 1_{\mathrm{i}, \mathrm{t}}+\gamma_{2} \mathrm{~L} 2_{\mathrm{i}, \mathrm{t}}+\gamma_{3} \mathrm{~L} 3_{\mathrm{i}, \mathrm{t}}+\gamma_{4}$ Rule144a $_{\mathrm{i}, \mathrm{t}}+\gamma_{5} \mathrm{~L} 1 *$ Invest $_{\mathrm{i}, \mathrm{t}}+\gamma_{6} \mathrm{~L} 2 *$ Invest $_{\mathrm{i}, \mathrm{t}}+$ $\gamma_{7}$ L3 $^{*}$ Invest $_{\mathrm{i}, \mathrm{t}}+\gamma_{8}$ Rule144a $^{*}$ Invest $_{\mathrm{i}, \mathrm{t}}+\gamma_{9}$ Invest $_{\mathrm{i}, \mathrm{t}}+$ Year $_{\mathrm{t}}+$ Firm $_{\mathrm{i}}+\mathrm{e}_{\mathrm{i}, \mathrm{t}}$

In addition to the variables already defined, L1 $*$ Invest $_{\mathrm{i}, \mathrm{t}}, \mathrm{L} 2 *$ Invest $_{\mathrm{i}, \mathrm{t}}, \mathrm{L} 3 *$ Invest $_{\mathrm{i}, \mathrm{t}}$, Rule144a $^{*}$ Invest $_{\mathrm{i}, \mathrm{t}}$ represent the interaction dummy variables and Invest $_{\mathrm{i}, \mathrm{t}}$ is a dummy variable, which equals one if the firm is deemed investable in year $t$. In this specification, the interaction dummy variables quantify the impact of listing on the dependent variables for joint investable/cross-listed firms, while the corresponding effects for previously non-investable cross-listed firms are captured by the sole cross listing dummies. The sum of both dummies quantifies the overall effect of listing. The coefficient estimates corresponding to equation 1 are presented in Tables 2 and 3, while Tables 4 and 5 contains analogous information resulting from the estimation of equation 2 .

\section{Results}

We begin our analysis by adopting the standard approach to estimating the effects of cross listing on corporate financing decisions. In particular, we estimate equation 1, where we distinguish ADR issues by type but ignore their place in the sequence of liberalization acts.

[INSERT TABLE 2 ABOUT HERE]

\footnotetext{
${ }^{7}$ Schmukler and Vesperoni (2006) do likewise, while Agca et al. (2008) regress the dependent variable on (oneperiod) lagged values of the independent variables. Our results remain unchanged when we adopt the latter approach and these are available from the corresponding author upon request.
} 
Table 2 presents results for our measures of capital structure. For the most part, our control variables are statistically significant and of the expected sign so we concentrate our discussion on the coefficients of the listing dummy variables. Both Level 1 and 2 listings increase their debt but only the latter increases its equity and in both cases there is little evidence that either changes its debt to equity ratio. It is noteworthy that neither class of firm has the right to raise capital in the US so increases in either form of financing must be sourced in non-US capital markets. The ADR issue appears to confer some benefits in terms of greater financing capacity but without a change in their relative price, since the overall capital structure remains statistically unchanged. In contrast, Level 3 and Rule 144a listings that have the right to raise capital in the US reduce their debt holdings and increase their equity levels. However, only the latter significantly changes its capital structure, with a move away from debt to equity financing. These results are generally in line with the extant literature. As we will show later, some of these insignificant results are driven by failing to take account of the differential behavior of firms whose financial liberalization has occurred in different sequences.

\section{[INSERT TABLE 3 ABOUT HERE]}

Table 3 reports the results of a similar analysis for the debt maturity ratios. Again the firm-level controls are as expected but now we see little statistical significance in relation to the coefficients on the listing dummies. Only Level 2 and Rule 144a firms appear to re-balance their debt portfolio with a reduction in the ratio of short-term debt to equity but this could simply be consistent with the finding in Table 2 that both increase equity post-listing. Taking the entire set of cross-listed firms as a single group suggests that there is little impact on the maturity structure of their debt.

We now extend the analysis to address the main issues of our paper, i.e. does the path to liberalization matter and for ADR lists, does the sequence of liberalization acts affect corporate financing choices? These questions are answered by estimating equation 2 and our results are presented in Table 4.

\section{[INSERT TABLE 4 ABOUT HERE]}

To shed light on whether or not the path to liberalization yields differential effects on the choice of capital structure, we compare the coefficients on the investability dummy with those of the sole cross listing dummies. Our results indicate that capital structure choice is largely unaffected by the path that constitutes the initial act of liberalization. Firms that are deemed to be investable through firm-level and 
country-level reforms behave similarly to those who achieve liberalization through the issuance of an ADR. Both sets of firms (with the exception of Level 1 ADR listings) reduce the debt component and increase the proportion of equity employed in financing operations. In the case of 'investable' firms and Level 2 ADRs, there is strong statistical evidence that they reduce both 'Book' and 'Net' Debt, while increasing both measures of equity. For Level 3 and Rule 144A listings, the coefficient signs are the same though some are not statistically different from zero. This is consistent with firms having restricted access to equity markets pre-liberalization and therefore being forced to operate with a sub-optimal capital structure. As firms become less constrained in their ability to raise equity capital, we observe a shift towards this form of financing. It also implies that the route to liberalization does not overly concern financial markets and all newly liberalized firms have greater access to equity markets after the event.

This finding leads us to naturally explore the second issue raised in this paper. We seek to quantify the potentially different effects of an ADR issue on the capital structure by focusing on whether the issue represents a first or second act of liberalization. We now compare the coefficients of the joint investable/cross listing dummies with those of the sole cross listing dummies. We have already seen that when an ADR is issued by a previously non-investable firm, they tend to take on more equity and reduce debt. This is in contrast to results reported in Table 2 where both debt and equity appear to increase. The difference can be explained by focusing on the behavior of firms who issue an ADR, having already being deemed 'investable'. These firms show no statistical evidence of a change in their equity component and in fact, the sign of the coefficient is usually negative suggesting a reduction in equity. Instead, these firms take on more debt. For Level 2 firms, this result is highly statistically significant. We surmise that the initial act of investability gives firms more access to equity markets while the subsequent ADR listing (and bonding to US governance regimes) allows them to take on more (possibly cheaper) debt. This may be due to firms having exhausted their demand for equity or it may be that the second act sends a stronger signal of the firm's creditworthiness to larger foreign debt markets. Emerging market corporate bond markets are generally small and thin, so the ADR issue subsequent to being investable may be required to re-assure international bond investors.

Level 1 firms who do not bond to the US and thus gain limited increases in shareholder protection post-listing, behave differently to other cross-listed firms. When the issuance of an ADR is the 
first act of liberalization, then there is some evidence that the proportion of debt financing increases but when the 'cross listing' occurs subsequent to being 'investable', then these firms behave more akin to the aforementioned Level 2 firms, with increases in debt and less equity employed in the corporation. Finally when ADRs are issued without being previously investable, Level 3 firms exhibit similar behavior to their Level 2 counterparts with a reduction in debt and higher levels of equity but there is no statistical significance of a change in their financing decisions when the ADR is subsequent to a previous act of liberalization. Arguably, this is due to the fact that these firms are likely to be the largest domestic firms and are already operating close to their optimal capital structure prior to the listing in the US. ${ }^{8}$ The key insight of Table 4 is that treating all firms issuing ADR's as a single group is likely to mask the true impact on capital structure decisions when the group mixes those who were previously deemed investable with those who are attaining this status for the first time. The first act of liberalization is associated with an increase in equity stakeholders and a reduction in debt, while corporations who cross-list despite being already open to foreign investors appear to finance their subsequent expansions with increasing proportions of debt. Another way to interpret our results can be related to the findings of Lins et al. (2005) who show that the largest post-listing increase in equity issuance is associated with emerging market firms. This is consistent with our findings for the first act of liberalization, while the second act leads these firms from emerging markets to behave more like developed market firms, i.e. smaller equity increases and relatively larger proportions of debt financing.

\section{[INSERT TABLE 5 ABOUT HERE]}

Our results for the maturity structure of corporate debt are reported in Table 5 . In contrast to the capital structure analysis, there is little evidence that the composition of the debt portfolio is affected by the sequencing of financial liberalization acts. Neither route to liberalization appears to yield statistically significant changes in our maturity measures.

Similarly, the placement of the ADR in the sequence of liberalization events has little effect on the choice of debt maturity. Focusing on the ratio of long-term to total debt, only Level 1 listed firms show a statistically significant change in behavior, post-listing. Specifically, they tend to reduce the proportion of long-term debt after the ADR listing when this constitutes an initial act of liberalization and

\footnotetext{
${ }^{8}$ Level 3 issues tend to be more expensive and thus more accessible to large corporations.
} 
the opposite effect is observed for cross listing firms who are already 'investable'. The first act appears to allow firms greater access to debt markets (from Table 4, we know these firms increase their proportion of debt financing relative to equity) but it's predominantly at the short-end of the maturity spectrum, signaling that debt holders still require the monitoring benefits of short-term debt. In the latter case, the ADR issue sends a stronger signal to the market and investors are now more confident in holding longerterm debt instruments of these firms. Looking at the debt to assets ratios, it appears that both forms of debt grow roughly in line with corporate assets while the proportions relative to equity remain unchanged except for firms with a Level 2 ADR. For these firms, both forms of debt fall relative to equity for firms who have not previously been liberalized (consistent with Table 4), while firms who issue an ADR after becoming 'investable' increase their debt portfolio in constant proportions.

Overall, ignoring the sequencing of ADR issues is less important for the composition of debt than the overall capital structure. We cannot identify differential effects between groups, as there is little statistical evidence of changes to our ratios.

\section{Conclusion}

We re-examine the effects of financial liberalization on both corporate capital structure and debt maturity choices for emerging market firms. We contrast two paths to liberalization; namely domestic reforms and improvements in corporate governance versus the issuance of an ADR program. We find corporate financing decisions do not differ between the two approaches. In both cases, firms tend to increase the proportion of equity financing and reduce their reliance on debt, post-liberalization. Furthermore, debt maturity choice is largely unaffected by either event.

We then explore if the 'timing' of the ADR in the sequence of liberalization events affects these decisions. We distinguish cross listing firms between those who have previously been deemed investable (due to the elimination of restrictions on foreign investors) and those whose ADR issuance is their first act of liberalization. This distinction is shown to be important. Treating all firms who issue ADRs as a single group masks important differences between firms who pursue different sequences of events to achieve financial liberalization. In particular, for all firms who choose to bond to the US governance regime (non Level 1), issuing an ADR is associated with a greater proportion of equity financing unless 
the firm has been previously deemed investable, in which case there is a reversal towards debt financing. It would seem that when the ADR constitutes the first act of liberalization, firms have greater access to equity markets but if already liberalized, the benefits accrue in the form of greater opportunity to take on debt, at possibly cheaper prices, due to the reinforcement of the firm's liberalized status. Level 1 ADRs only change their behavior when the ADR is the initial means of liberalization but in contrast to the other types of cross listing, these firms carry more debt. Given that there is no greater protection afforded to shareholders, they may not experience an increase in the demand for their equity. However, they are able to access more short-term debt due to the monitoring benefits of the listing.

Relative to capital structure choices, the sequence of liberalization events has less impact on the debt maturity decision. For Level 1 listings, the increase in debt for firms who are not previously deemed investable is predominantly in short-term debt (as argued above) while firms who had been liberalized prior to the ADR issue take on more long-term debt. Perhaps, the second act of financial liberalization convinces debt market participants of the credit-worthiness of the firm. For other firms, changes in debt holdings appear to be roughly constant, so even when there is an expansion of the debt portfolio, there is no evidence of re-balancing between long- and short-term instruments.

In summary, our analysis highlights the importance of distinguishing between types of liberalization act and the sequence in which events occur. Both paths to liberalization produce similar changes to corporate financing decisions. We could argue that the once liberalized, firms from emerging markets behave more like their counterparts from developed markets and therefore a subsequent ADR issue affects corporate financing decision differently that it would had it been the initial approach to investability. 


\section{References}

1. Agca, S. De Nicolo, G. and E. Detragiache, E, 2007, Financial reforms, financial openness, and corporate borrowing: International evidence, IMF working paper No. 186, International Monetary Fund, Washington.

2. Bank of New York, 2005, The Depositary Receipts Markets 2005 Yearbook.

3. Barclay, M.J. and C.W. Smith, 1995, The maturity structure of corporate debt, Journal of Finance 50, 609-631.

4. Bekaert, G. Harvey, C. and C. Lundblad, 2005, Does financial liberalization spur growth? Journal of Financial Economics 77, 3-55.

5. Chari, A. and P. Henry, 2004, Is the invisible hand discerning or indiscriminate? Investment and stock prices in the aftermath of capital account liberalizations, Working paper, Stanford University.

6. Charitou, A. and C. Louca, 2009, Cross listing and operating performance: evidence from exchange-listed American depositary receipts, Journal of Business, Finance and Accounting 36, $99-129$.

7. Datta, S. Iskandar-Datta, M. and K. Raman, 2005, Managerial stock ownership and the maturity structure of corporate debt, Journal of Finance 60, 2333-2350.

8. Fan, J.P.H. Titman, S. and G. Twite, 2008, An international comparison of capital structure and debt maturity choices, Working paper, University of Texas at Austin.

9. Gupta, N. and K. Yuan, 2004, On the growth effects of stock market liberalizations, Working paper, Indiana University.

10. Henry, P.B, 2000, Do stock market liberalizations cause investment booms? Journal of Financial Economics 58, 301-334.

11. Khurana, I.K. Martin, X, and R. Periera, 2008, Cross listing and firm growth, Review of Finance 12, 293-322.

12. Li, Z. 2003, Equity market liberalizations and economic performance, Working paper, Princeton University. 
13. Lins, K. Strickland, D, and M. Zenner, 2005, Do non-U.S. firms issue equity on U.S. stock exchanges to relax capital constraints? Journal of Financial and Quantitative Analysis 40(1), 109133.

14. Mitton, T, 2006, Stock market liberalization and operating performance at the firm level, Journal of Financial Economics 81, 625-647.

15. Mitton, T, 2007, Why have debt ratios increased for firms in emerging markets? European Financial Management 14(1), 127-151.

16. Reese, W., and M. Weisbach, 2002, Protection of minority shareholder interests, cross listings in the United States, and subsequent equity offerings, Journal of Financial Economics 66, 65-104.

17. Sarkissian, S. and M.J. Schill, 2009, Are there permanent valuation gains to overseas listings? Review of Financial Studies 22(1), 371-412.

18. Schmukler, S.L. and E. Vesperoni, 2006, Financial globalization and debt maturity in emerging markets, Journal of Development Economics 79, 183-207.

19. Siegel, J, 2008, Is there a better commitment mechanism than cross listings for emerging market firms? Evidence from Mexico, Working paper, Harvard Business School.

20. White, H, 1980, A heteroskedasticity-consistent covariance matrix estimator and a direct test for heteroskedasticity, Econometrica 48, 817-838.

21. Wu, C.Y, 2008, Consequences of cross listing in the U.S: changes in leverage and corporate governance, Working paper, Arizona State University. 
TABLE 1

Sample Description

The table reports summary statistics of the sample by country. All information on ADRs is sourced from the Bank of New York, Citibank, NYSE, and NASDAQ. Level 1, Level 2/3 and Rule 144a are firms that cross-list in the U.S., either as Level 1 Over-the-Counter, Level 2/3 exchange traded, or Rule 144a issues on Portal, as indicated. For each ADR level, I also report the number of each that was also previously deemed investable (i.e., \& I). Diff refers to the median difference between the year in which the firm cross-lists and the year it initially becomes investable. $\mathrm{N}$ is the number of firms and \#Obs is the number of firm-year observations. Investable dates are taken from the Emerging Markets Database (EMDB). Median/Std Dev Diff is the median/standard deviation time (in years) between the year in which a firm is deemed investable and subsequently cross-lists.

\begin{tabular}{|c|c|c|c|c|c|c|c|c|c|c|c|c|c|c|c|}
\hline & \multicolumn{2}{|c|}{ Sample } & \multicolumn{5}{|c|}{ Invest \& ADR } & \multicolumn{2}{|c|}{ Level 1} & \multicolumn{2}{|c|}{ Level 2} & \multicolumn{2}{|c|}{ Level 3} & \multicolumn{2}{|c|}{ Rule $144 \mathrm{a}$} \\
\hline & $\mathrm{N}$ & \#Obs & Invest & ADR & $\begin{array}{c}\text { ADR \& } \\
\text { I }\end{array}$ & $\begin{array}{c}\text { Median } \\
\text { Diff } \\
\end{array}$ & $\begin{array}{c}\text { Std Dev } \\
\text { Diff }\end{array}$ & Level 1 & $\begin{array}{c}\text { Level } 1 \\
\& \text { I } \\
\end{array}$ & Level 2 & $\begin{array}{c}\text { Level } 2 \\
\& \text { I }\end{array}$ & Level 3 & $\begin{array}{c}\text { Level } 3 \\
\& \text { I } \\
\end{array}$ & $144 a$ & $\begin{array}{c}144 a \text { \& } \\
\text { I }\end{array}$ \\
\hline Argentina & 49 & 393 & 11 & 1 & 1 & 1 & - & 1 & 1 & 0 & 0 & $\overline{0}$ & 0 & 0 & 0 \\
\hline Brazil & 224 & 1,867 & 37 & 19 & 14 & 3 & 2.79 & 9 & 7 & 6 & 5 & 0 & 0 & 4 & 2 \\
\hline Chile & 138 & 1,384 & 33 & 8 & 7 & 4 & 1.60 & 0 & 0 & 5 & 5 & 3 & 2 & 0 & 0 \\
\hline China & 1,395 & 8,124 & 37 & 10 & 5 & 3 & 1.03 & 9 & 4 & 0 & 0 & 1 & 1 & 0 & 0 \\
\hline Colombia & 25 & 208 & 7 & 2 & 2 & 2 & 0.50 & 0 & 0 & 0 & 0 & 0 & 0 & 2 & 2 \\
\hline Egypt & 20 & 109 & 7 & 1 & 1 & 2 & - & 0 & 0 & 0 & 0 & 0 & 0 & 1 & 1 \\
\hline Greece & 219 & 1,756 & 41 & 3 & 3 & 8 & 3.05 & 0 & 0 & 1 & 1 & 1 & 1 & 1 & 1 \\
\hline Hungary & 28 & 212 & 3 & 2 & 2 & 1 & 0.00 & 1 & 1 & 0 & 0 & 0 & 0 & 1 & 1 \\
\hline India & 554 & 4,119 & 66 & 24 & 12 & 2 & 0.65 & 1 & 1 & 3 & 2 & 2 & 1 & 18 & 8 \\
\hline Israel & 101 & 652 & 17 & 1 & 0 & - & - & 0 & 0 & 0 & 0 & 0 & 0 & 1 & 0 \\
\hline Korea & 830 & 6,308 & 98 & 12 & 7 & 5 & 1.68 & 2 & 1 & 1 & 1 & 1 & 1 & 8 & 4 \\
\hline Malaysia & 828 & 7,018 & 94 & 6 & 4 & 11 & 5.02 & 6 & 4 & 0 & 0 & 0 & 0 & 0 & 0 \\
\hline Mexico & 77 & 750 & 19 & 13 & 10 & 8 & 3.63 & 6 & 4 & 4 & 3 & 1 & 1 & 2 & 2 \\
\hline Peru & 57 & 414 & 14 & 3 & 3 & 3 & 0.51 & 0 & 0 & 1 & 1 & 1 & 1 & 1 & 1 \\
\hline Philippines & 130 & 1,076 & 23 & 5 & 3 & 6 & 1.00 & 1 & 0 & 1 & 1 & 0 & 0 & 3 & 2 \\
\hline Poland & 139 & 844 & 18 & 3 & 2 & 1 & 0.00 & 1 & 1 & 0 & 0 & 0 & 0 & 2 & 1 \\
\hline Russia & 22 & 128 & 5 & 7 & 4 & 1 & 0.48 & 4 & 2 & 2 & 2 & 0 & 0 & 1 & 0 \\
\hline South Africa & 235 & 2,253 & 29 & 18 & 13 & 2 & 2.42 & 12 & 7 & 4 & 4 & 0 & 0 & 2 & 2 \\
\hline Taiwan & 1,169 & 7,486 & 89 & 40 & 17 & 3 & 2.01 & 0 & 0 & 2 & 2 & 3 & 1 & 35 & 14 \\
\hline Thailand & 370 & 3,438 & 49 & 8 & 6 & 4 & 2.35 & 8 & 6 & 0 & 0 & 0 & 0 & 0 & 0 \\
\hline Turkey & 178 & 1,326 & 30 & 1 & 1 & 1 & - & 0 & 0 & 0 & 0 & 0 & 0 & 1 & 1 \\
\hline \multirow[t]{2}{*}{ Venezuela } & 9 & 80 & 4 & 2 & 2 & 1 & 0.00 & 2 & 2 & 0 & 0 & 0 & 0 & 0 & 0 \\
\hline & 6,797 & 49,945 & 731 & 189 & 119 & 3 & 3.12 & 63 & 41 & 30 & 27 & 13 & 6 & 83 & 42 \\
\hline
\end{tabular}




\section{TABLE 2}

\begin{tabular}{|c|c|c|c|c|c|}
\hline & Book Debt & Net Debt & Log (Equity) & Equity/Assets & Debt-Equity \\
\hline Level 1 & $0.028^{* * *}$ & $0.034 * * *$ & $-0.162 *$ & -4.001 & 0.133 \\
\hline & {$[2.77]$} & {$[2.81]$} & {$[1.91]$} & {$[1.27]$} & [1.29] \\
\hline Level 2 & $0.027 * * *$ & $0.022^{*}$ & $0.277 * * *$ & 4.015 & -0.089 \\
\hline & {$[2.60]$} & [1.86] & {$[3.41]$} & [1.43] & [1.09] \\
\hline Level 3 & $-0.041 *$ & $-0.108 * * *$ & $0.534 * * *$ & $5.489 * * *$ & 0.133 \\
\hline & [1.66] & [3.20] & [2.99] & [3.26] & {$[0.93]$} \\
\hline Rule $144 a$ & $-0.023^{* * *}$ & $-0.042 * * *$ & $0.279 * * *$ & 1.675 & $-0.212^{* *}$ \\
\hline & [2.88] & [4.44] & [3.18] & {$[0.68]$} & [2.54] \\
\hline Tangibility & $0.137 * * *$ & $0.498^{* * *}$ & 0.078 & $-34.475^{* * *}$ & $0.235 * * *$ \\
\hline & [16.82] & {$[48.45]$} & {$[0.75]$} & [10.56] & [3.17] \\
\hline Size & $0.020 * * *$ & $0.035^{* * *}$ & -0.015 & $-9.921 * * *$ & $0.156^{* * *}$ \\
\hline & [13.34] & [18.91] & {$[0.71]$} & [15.53] & [10.12] \\
\hline Profitability & $-0.409 * * *$ & $-0.471 * * *$ & $-1.756^{* * *}$ & $23.304 * * *$ & $-1.267 * * *$ \\
\hline & [37.33] & [37.88] & [11.64] & [7.04] & [10.94] \\
\hline Growth Opportunities & $0.001 * * *$ & $0.001 * * *$ & $0.316^{* * *}$ & $1.719^{* * *}$ & $-0.124 * * *$ \\
\hline & [4.38] & [0.68] & [20.24] & [3.92] & [13.21] \\
\hline Time Dummies & Yes & Yes & Yes & Yes & Yes \\
\hline \# Observations & 49,945 & 49,945 & 49,945 & 49,945 & 49,945 \\
\hline R-Squared & 0.142 & 0.180 & 0.006 & 0.048 & 0.044 \\
\hline
\end{tabular}




\section{TABLE 3}

This table reports coefficient estimates from firm-fixed effects regressions with t-statistics (absolute value), adjusted for heteroskedasticity, in parentheses. The dependent variable is long-term debt to assets, short-term debt to assets, long-term debt to equity, short-term debt to equity, or long-term debt to total debt as indicated. ADR variables are dummy variables that are set equal to one in years in which the firm has an ADR of the specified type. The control variables are defined in the main text. Also estimated but not reported are a constant, and a full set of year dummies. Statistical significance is denoted by ***, **, * for the $1 \%, 5$, and $10 \%$ levels, respectively.

\begin{tabular}{|c|c|c|c|c|c|}
\hline & LTD Assets & STD Assets & LTD Equity & STD Equity & LTD Total \\
\hline \multirow[t]{2}{*}{ Level 1} & 0.008 & 0.047 & 0.079 & 0.062 & -0.003 \\
\hline & {$[0.91]$} & [1.47] & {$[1.56]$} & [1.11] & {$[0.13]$} \\
\hline \multirow[t]{2}{*}{ Level 2} & $0.017 *$ & 0.079 & -0.012 & $-0.078^{* *}$ & -0.010 \\
\hline & [1.94] & [1.42] & {$[0.26]$} & [2.00] & {$[0.58]$} \\
\hline \multirow[t]{2}{*}{ Level 3} & -0.012 & 0.001 & 0.090 & -0.214 & -0.060 \\
\hline & {$[0.63]$} & {$[0.01]$} & [0.59] & {$[1.40]$} & {$[1.36]$} \\
\hline \multirow[t]{2}{*}{ Rule $144 a$} & -0.010 & 0.032 & -0.061 & $-0.104^{* *}$ & 0.007 \\
\hline & [1.08] & {$[0.90]$} & [1.44] & [2.45] & {$[0.41]$} \\
\hline \multirow[t]{2}{*}{ Tangibility } & $0.104 * *$ & -0.520 & $0.376^{* * *}$ & $-0.237 * * *$ & $0.282^{* * *}$ \\
\hline & [2.15] & {$[1.24]$} & [10.95] & [5.08] & [20.60] \\
\hline \multirow[t]{2}{*}{ Size } & 0.003 & -0.099 & $0.089 * * *$ & $0.078^{* * *}$ & $0.028^{* * *}$ \\
\hline & [0.68] & [1.21] & [13.25] & [8.35] & [11.11] \\
\hline \multirow[t]{2}{*}{ Profitability } & $-0.201 * * *$ & $-1.044^{* *}$ & $-0.328^{* * *}$ & $-0.801 * * *$ & $0.094 * * *$ \\
\hline & [3.67] & [2.10] & [6.96] & [11.50] & [5.98] \\
\hline \multirow[t]{2}{*}{ Growth Opportunities } & $0.024 * * *$ & 0.094 & $-0.043^{* * *}$ & $-0.069 * * *$ & $-0.010^{* * *}$ \\
\hline & [3.13] & [1.57] & [9.74] & [12.27] & {$[2.75]$} \\
\hline Time Dummies & Yes & Yes & Yes & Yes & Yes \\
\hline \# Observations & 49,945 & 49,945 & 49,945 & 49,945 & 49,945 \\
\hline R-Squared & 0.022 & 0.003 & 0.060 & 0.036 & 0.134 \\
\hline
\end{tabular}




\section{TABLE 4}

This table reports coefficient estimates from firm-fixed effects regressions with t-statistics (absolute value), adjusted for heteroskedasticity, in parentheses. The dependent variable is book debt, net debt to total assets, $\log$ (Equity), equity to assets, or debt to equity as indicated. ADR variables are dummy variables that are set equal to one in years in which the firm has an ADR of the specified type. Investable is a dummy variable that is set equal to one in years in which the firm is designated as investable. The control variables are defined in the main text. Also estimated but not reported are a constant, and a full set of year dummies. Statistical significance is denoted by $* * *, * *, *$ for the $1 \%, 5$, and $10 \%$ levels, respectively.

\begin{tabular}{|c|c|c|c|c|c|}
\hline & Book Debt & Net Debt & Log (Equity) & Equity/Assets & Debt-Equity \\
\hline \multirow[t]{2}{*}{ Level 1} & 0.015 & -0.010 & 0.120 & $6.842 * * *$ & $0.247 *$ \\
\hline & [0.82] & {$[0.30]$} & {$[0.75]$} & {$[3.46]$} & [1.92] \\
\hline \multirow[t]{2}{*}{ Level 2} & $-0.129 * * *$ & $-0.177 * * *$ & $0.608^{* * *}$ & $5.329 * *$ & $-1.321 * *$ \\
\hline & [2.64] & [2.92] & [2.69] & {$[2.00]$} & [2.31] \\
\hline \multirow[t]{2}{*}{ Level 3} & -0.031 & $-0.129 * *$ & $0.637 * * *$ & 4.256 & 0.090 \\
\hline & {$[0.68]$} & [2.24] & [2.69] & [1.49] & {$[0.53]$} \\
\hline \multirow[t]{2}{*}{ Rule $144 a$} & -0.012 & $-0.049 * * *$ & 0.216 & -9.371 & $-0.214^{*}$ \\
\hline & {$[1.04]$} & {$[3.37]$} & {$[1.23]$} & [1.43] & [1.94] \\
\hline \multirow[t]{2}{*}{ Level $1 *$ Investable } & 0.014 & $0.052^{*}$ & $-0.354^{*}$ & $-14.121 * * *$ & -0.154 \\
\hline & {$[0.65]$} & [1.95] & [1.91] & [3.12] & {$[0.85]$} \\
\hline \multirow[t]{2}{*}{ Level $2 *$ Investable } & $0.164^{* * *}$ & $0.211^{* * *}$ & -0.324 & -1.141 & $1.323^{* *}$ \\
\hline & [3.30] & [3.42] & {$[1.35]$} & [0.29] & {$[2.30]$} \\
\hline \multirow[t]{2}{*}{ Level $3 *$ Investable } & -0.017 & 0.023 & -0.099 & 1.898 & 0.050 \\
\hline & {$[0.31]$} & [0.33] & {$[0.31]$} & {$[0.55]$} & {$[0.20]$} \\
\hline \multirow[t]{2}{*}{ Rule $144 \mathrm{a} *$ Investable } & -0.018 & 0.012 & 0.101 & $16.978^{* *}$ & 0.001 \\
\hline & [1.14] & {$[0.62]$} & {$[0.51]$} & [2.54] & {$[0.01]$} \\
\hline \multirow[t]{2}{*}{ Investable } & $-0.012 * * *$ & $-0.017 * * *$ & $0.127 * * *$ & 0.809 & -0.021 \\
\hline & [3.89] & {$[4.57]$} & [3.72] & {$[0.69]$} & {$[0.65]$} \\
\hline \multirow[t]{2}{*}{ Tangibility } & $0.137 * * *$ & $0.498^{* * *}$ & 0.075 & $-34.558^{* * *}$ & $0.232^{* * *} *$ \\
\hline & [16.82] & {$[48.57]$} & {$[0.73]$} & [10.58] & [3.13] \\
\hline \multirow[t]{2}{*}{ Size } & $0.021 * * *$ & $0.035^{* * *}$ & -0.016 & $-9.936 * * *$ & $0.156^{* * *}$ \\
\hline & {$[13.45]$} & [19.05] & {$[0.79]$} & [15.55] & [10.14] \\
\hline \multirow[t]{2}{*}{ Profitability } & $-0.409 * * *$ & $-0.471 * * *$ & $-1.751 * * *$ & $23.329 * * *$ & $-1.267 * * *$ \\
\hline & {$[37.36]$} & [37.93] & {$[11.60]$} & [7.05] & {$[10.93]$} \\
\hline \multirow[t]{2}{*}{ Growth Opportunities } & $0.005^{* * *}$ & 0.001 & $0.316^{* * *}$ & $1.713^{* * *}$ & $-0.124 * * *$ \\
\hline & {$[4.40]$} & {$[0.70]$} & [20.22] & {$[3.90]$} & [13.22] \\
\hline Time Dummies & Yes & Yes & Yes & Yes & Yes \\
\hline \# Observations & 49,945 & 49,945 & 49,945 & 49,945 & 49,945 \\
\hline R-Squared & 0.144 & 0.181 & 0.007 & 0.048 & 0.044 \\
\hline
\end{tabular}




\section{TABLE 5}

This table reports coefficient estimates from firm-fixed effects regressions with t-statistics (absolute value), adjusted for heteroskedasticity, in parentheses. The dependent variable is long-term debt to assets, short-term debt to assets, long-term debt to equity, short-term debt to equity, or long-term debt to total debt as indicated. ADR variables are dummy variables that are set equal to one in years in which the firm has an ADR of the specified type. Investable is a dummy variable that is set equal to one in years in which the firm is designated as investable. The control variables are defined in the main text. Also estimated but not reported are a constant, and a full set of year dummies. Statistical significance is denoted by $* * *, * *, *$ for the $1 \%, 5$, and $10 \%$ levels, respectively.

\begin{tabular}{|c|c|c|c|c|c|}
\hline & LTD Assets & STD Assets & LTD Equity & STD Equity & LTD Total \\
\hline Level 1 & $\begin{array}{r}-0.011 \\
{[074]}\end{array}$ & $\begin{array}{l}0.069 \\
1.51]\end{array}$ & $\begin{array}{l}0.079 \\
{[0.99]}\end{array}$ & $\begin{array}{c}0.166^{* *} \\
{[222]}\end{array}$ & $\begin{array}{c}-0.076^{* *} \\
{[2.42]}\end{array}$ \\
\hline Level 2 & $\begin{array}{l}-0.040 \\
{[1.26]}\end{array}$ & $\begin{array}{l}0.054 \\
{[0.51]}\end{array}$ & $\begin{array}{c}-0.572^{* *} \\
{[2.10]}\end{array}$ & $\begin{array}{c}-0.724 * * * \\
{[2.60]}\end{array}$ & $\begin{array}{l}0.037 \\
{[0.71]}\end{array}$ \\
\hline Level 3 & $\begin{array}{r}-0.017 \\
{[0.47]}\end{array}$ & $\begin{array}{l}0.053 \\
{[0.71]}\end{array}$ & $\begin{array}{l}0.093 \\
{[0.64]}\end{array}$ & $\begin{array}{r}-0.017 \\
{[0.40]}\end{array}$ & $\begin{array}{l}-0.129 \\
{[1.28]}\end{array}$ \\
\hline Rule $144 a$ & $\begin{array}{l}0.004 \\
{[0.35]}\end{array}$ & $\begin{array}{l}0.024 \\
{[0.86]}\end{array}$ & $\begin{array}{c}-0.059 \\
{[1.11]}\end{array}$ & $\begin{array}{c}-0.099 * * * \\
{[2.79]}\end{array}$ & $\begin{array}{l}0.055 \\
{[1.59]}\end{array}$ \\
\hline Level $1 *$ Investable & $\begin{array}{l}0.024 \\
{[1.36]}\end{array}$ & $\begin{array}{r}-0.030 \\
{[0.98]}\end{array}$ & $\begin{array}{l}0.001 \\
{[0.01]}\end{array}$ & $\begin{array}{r}-0.141 \\
{[1.38]}\end{array}$ & $\begin{array}{c}0.097 * * \\
{[2.47]}\end{array}$ \\
\hline Level $2 *$ Investable & $\begin{array}{l}0.061^{*} \\
{[1.86]}\end{array}$ & $\begin{array}{l}0.026 \\
{[0.37]}\end{array}$ & $\begin{array}{c}0.604^{* *} \\
{[2.19]}\end{array}$ & $\begin{array}{c}0.689 * * \\
{[2.46]}\end{array}$ & $\begin{array}{l}-0.050 \\
{[0.91]}\end{array}$ \\
\hline Level $3 *$ Investable & $\begin{array}{l}0.004 \\
{[0.10]}\end{array}$ & $\begin{array}{l}-0.072 \\
{[1.04]}\end{array}$ & $\begin{array}{l}-0.004 \\
{[0.02]}\end{array}$ & $\begin{array}{c}-0.265 \\
{[1.31]}\end{array}$ & $\begin{array}{l}0.090 \\
{[0.81]}\end{array}$ \\
\hline Rule $144 \mathrm{a} *$ Investable & $\begin{array}{l}-0.019 \\
{[1.32]}\end{array}$ & $\begin{array}{l}0.011 \\
{[0.44]}\end{array}$ & $\begin{array}{l}-0.002 \\
{[0.03]}\end{array}$ & $\begin{array}{l}-0.010 \\
{[0.13]}\end{array}$ & $\begin{array}{c}-0.072^{*} \\
{[1.79]}\end{array}$ \\
\hline Investable & $\begin{array}{c}-0.004 \\
{[1.10]}\end{array}$ & $\begin{array}{r}-0.010 \\
{[1.31]}\end{array}$ & $\begin{array}{r}-0.001 \\
{[0.04]}\end{array}$ & $\begin{array}{r}-0.028 \\
{[1.41]}\end{array}$ & $\begin{array}{l}0.001 \\
{[0.10]}\end{array}$ \\
\hline Tangibility & $\begin{array}{c}0.104^{* *} \\
{[2.15]}\end{array}$ & $\begin{array}{l}-0.520 \\
{[1.24]}\end{array}$ & $\begin{array}{c}0.374^{* * *} \\
{[10.92]}\end{array}$ & $\begin{array}{c}-0.239 * * * \\
{[5.12]}\end{array}$ & $\begin{array}{c}0.283^{* * * *} \\
{[20.64]}\end{array}$ \\
\hline Size & $\begin{array}{l}0.003 \\
{[0.69]}\end{array}$ & $\begin{array}{l}-0.099 \\
{[1.21]}\end{array}$ & $\begin{array}{c}0.089 * * * \\
{[13.27]}\end{array}$ & $\begin{array}{c}0.078^{* * *} \\
{[8.40]}\end{array}$ & $\begin{array}{c}0.028^{* * *} \\
{[11.13]}\end{array}$ \\
\hline Profitability & $\begin{array}{c}-0.201 * * * \\
{[3.68]}\end{array}$ & $\begin{array}{c}-1.044 * * \\
{[2.10]}\end{array}$ & $\begin{array}{c}-0.328^{* * *} \\
{[6.95]}\end{array}$ & $\begin{array}{c}-0.807 * * * \\
{[11.51]}\end{array}$ & $\begin{array}{c}0.095^{* * *} \\
{[5.98]}\end{array}$ \\
\hline Growth Opportunities & $\begin{array}{c}0.024 * * * \\
{[3.13]}\end{array}$ & $\begin{array}{l}0.094 \\
{[1.57]}\end{array}$ & $\begin{array}{c}-0.043 * * * \\
{[9.75]}\end{array}$ & $\begin{array}{c}-0.069 * * * \\
{[12.28]}\end{array}$ & $\begin{array}{c}-0.005^{* * *} \\
{[2.72]}\end{array}$ \\
\hline $\begin{array}{l}\text { Time Dummies } \\
\text { \# Observations } \\
\text { R-Squared }\end{array}$ & $\begin{array}{c}\text { Yes } \\
49,945 \\
0.022\end{array}$ & $\begin{array}{c}\text { Yes } \\
49,945 \\
0.003\end{array}$ & $\begin{array}{c}\text { Yes } \\
49,945 \\
0.060\end{array}$ & $\begin{array}{c}\text { Yes } \\
49,945 \\
0.036\end{array}$ & $\begin{array}{c}\text { Yes } \\
49,945 \\
0.133\end{array}$ \\
\hline
\end{tabular}




\section{Figure 1}

The left panel displays the median book debt, net debt (to assets), equity to assets, debt-to-equity, long-term debt to total debt, long-term debt to equity, long-term debt to assets, short-tem debt to equity, and short-term debt to assets for all Level 1 firms in the sample, before and after cross listing in the United States, Level 1 firms that were also previously investable, and for Level 1 firms that were previously not deemed investable, before and after cross listing in the United States. The right panel displays the same ratios for Rule 144a firms.
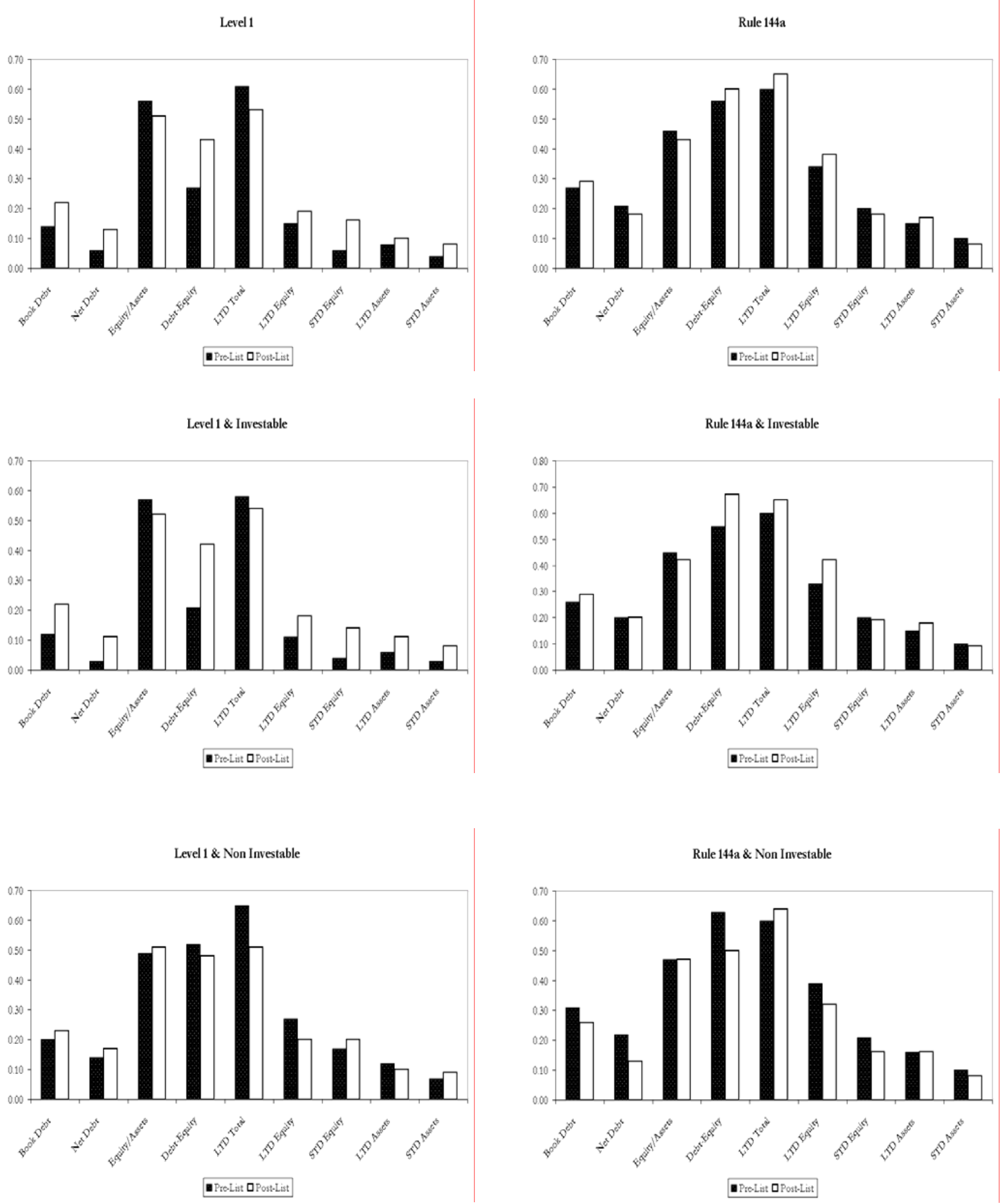
Figure 2

The left panel displays the median book debt, net debt (to assets), equity to assets, debt-to-equity, long-term debt to total debt, long-term debt to equity, long-term debt to assets, short-tem debt to equity, and short-term debt to assets for all Level 2 firms in the sample, before and after cross listing in the United States, Level 2 firms that were also previously investable, and for Level 2 firms that were previously not deemed investable, before and after cross listing in the United States. The right panel displays the same ratios for Level 3 firms.
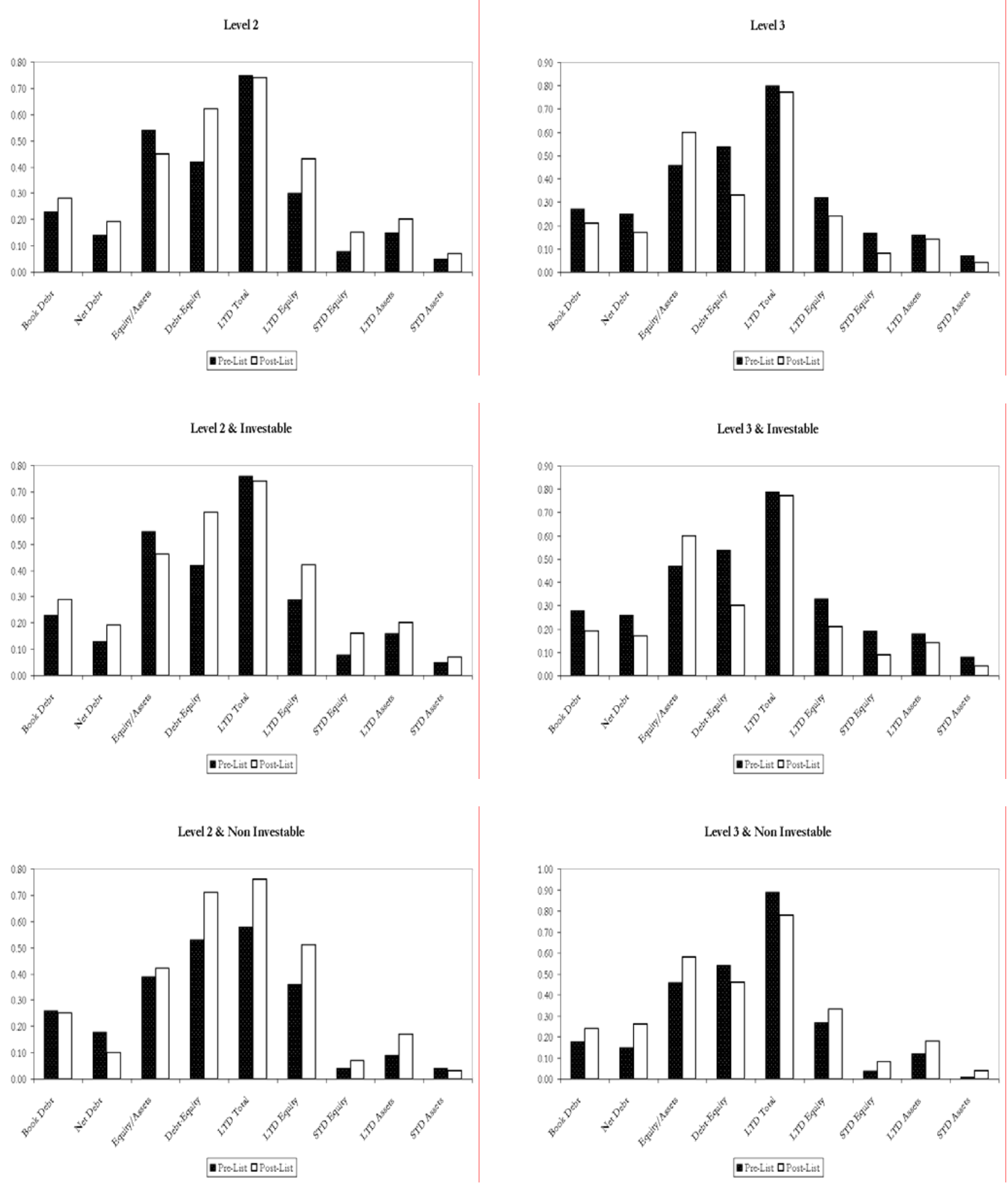
Figure 3

The left panel displays the median log equity (US\$) for all Level 1, Level 2, Level 3, and Rule 144a firms in the sample, before and after cross listing in the United States, Level 1, 2, 3, and 144a firms that were also previously investable, and for Level 1, 2, 3 , and 144a firms, respectively that were previously not deemed investable, before and after cross listing in the United States.
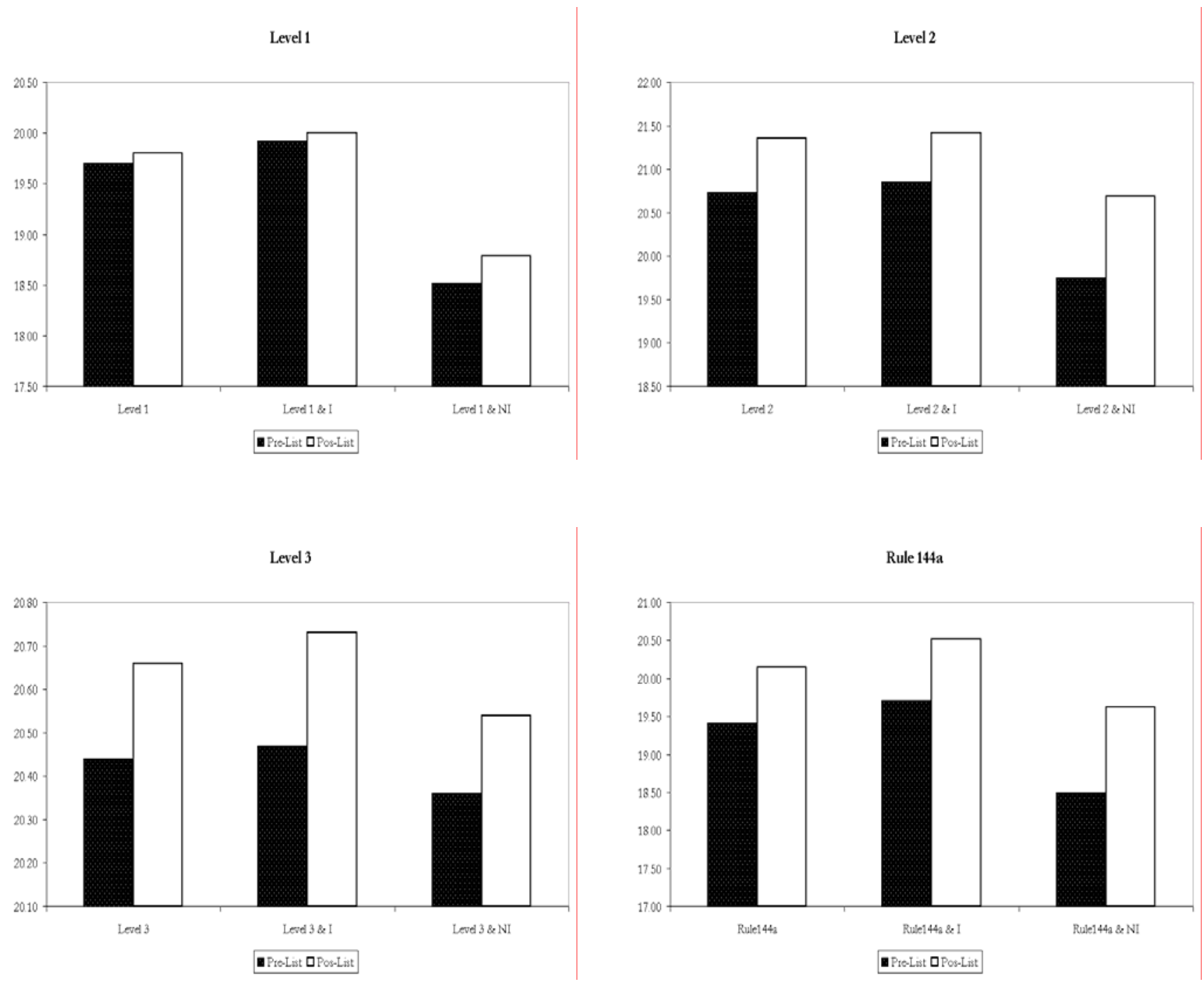